\title{
ВЫЯВЛЕНИЕ ЗАВИСИМОСТИ СОСТАВА И УСЛОВИЙ ОБРАЗОВАНИЯ ПИКРОИЛЬМЕНИТОВ ТРУБКИ ЗАРНИЦА (ЯкУтия) ПО ДАННЫМ ТЕРМОМАГНИТНЫХ ИССЛЕДОВАНИЙ
}

\author{
Ш.3. Ибрагимов, С.Г. Мишенин*, Ю.Н. Осин** \\ Казанский (Приволжский) федеральный университет, Институт геологии и нефтегазовых технологий, \\ 420111, Казань, ул. Кремлевская, 4/5, Россия \\ * Институт геологии и минералогии им. В.С. Соболева СО РАН, \\ 630090, Новосибирск, просп. Академика Коптюга, 3, Россия \\ ** Казанский (Приволжский) федеральный университет, Междисииплинарный Центр аналитической микроскопии, \\ 420018, Казань, ул. Кремлевская, 18, Россия
}

Проведено исследование 737 образцов пикроильменита из керна восьми скважин субмеридионального бурового профиля тр. Зарница Далдынского кимберлитового поля Якутии. По всем образцам был проведен термомагнитный анализ. По данным термомагнитного анализа отобраны 29 типовых образцов, критерием отбора было различие вида термомагнитных кривых и температуры Кюри. По этой выборке проведены детальные микрозондовые исследования с целью определения зависимости параметров, описывающих термомагнитные кривые от содержания гематитового минала в пикроильменитах.

Термомагнитные кривые подавляющего большинства образцов пикроильменита тр. Зарница аппроксимируются моделью с двумя распределениями содержания гематитового минала. Большую часть зерна пикроильменита можно описать основным распределением, меньшую часть - дополнительным распределением. Среднее значение гематитового минала основного распределения совпадает с данными микрозондовых исследований, среднее значение дополнительного распределения всегда больше, чем среднее значение основного распределения.

На основании анализа соотношения основного и дополнительного распределений по объему зерен пикроильменита различных скважин сделаны выводы о сравнительной динамике образования пикроильменита в различных участках тр. Зарница. Также сделан вывод о многоактном становлении кимберлитового тела в меняющихся термодинамических условиях, что обусловило сложный характер распределения пикроильменита.

Пикроильменит, термомагнитный анализ, температура Кюри, содержание гематитового минала в пикроильмените, магнетит, кимберлитовая трубка.

\section{DEPENDENCE OF THE COMPOSITION OF THE ZARNITSA PIPE PICROILMENITES (Yakutia) ON THEIR FORMATION CONDITIONS (from data of thermomagnetic studies)}

\section{Sh.Z. Ibragimov, S.G. Mishenin, and Yu.N. Osin}

A thermomagnetic analysis has been performed for 737 picroilmenite samples from the cores of eight boreholes in the N-S-striking drilling profile of the Zarnitsa kimberlite pipe in the Daldyn kimberlite field, Yakutia. Based on the shapes of thermomagnetic curves and the Curie points, 29 samples were chosen for detailed microprobe studies of chemical composition and elucidation of the dependence of their thermomagnetic parameters on the content of the hematite end-member in the picroilmenites.

The thermomagnetic curves of most of the studied picroilmenite samples are approximated by a twocomponent model for the hematite end-member distribution: the main and supplementary distribution. The average hematite end-member content in the main distribution coincides with the probe microanalysis data and is always lower than the average content in the supplementary distribution.

The relative hematite end-member contents in the main and supplementary distributions within the picroilmenite grains are indicators of the dynamics of the mineral formation in different parts of the Zarnitsa pipe. The data obtained testify to the multistage formation of the pipe under unstable thermodynamic conditions, which explains the intricate distribution pattern of picroilmenite.

Picroilmenite, thermomagnetic analysis, Curie point, content of the hematite end-member in picroilmenite, magnetite, kimberlite pipe

\section{ВВЕДЕНИЕ}

Пикроильменит относится к промежуточным членам изоморфной серии твердых растворов $\mathrm{Fe}_{2} \mathrm{O}_{3}$ (гематит) - $\mathrm{FeTiO}_{3}$ (ильменит) - $\mathrm{MgTiO}_{3}$ (гейкилит). Пироп и пикроильменит являются главными ак- 
цессорными минералами кимберлитовых трубок и индикаторами термодинамических обстановок их формирования.

Минералогические и геохимические исследования пикроильменита из тр. Зарница проведены авторами работ [Амшинский, Похиленко, 1983; Алымова, Костровицкий, 2002; Бовкун и др., 2005]. В этих работах определены особенности вещественного состава пикроильменита из тр. Зарница, сделаны выводы об условиях их кристаллизации.

Одним из основных факторов, определяющих состав пикроильменита кимберлитов, является глубина заложения магматических очагов кимберлитовых расплавов в неоднородной верхней мантии. Помимо глубины заложения важная роль принадлежит динамике развития очага каждого конкретного тела [Бовкун и др., 2005].

Многими авторами отмечается наличие реакционных кайм на макро- и мегакристах пикроильменита [Геншафт, Илупин, 1982; Клопов и др., 1984; Гаранин и др., 1986; Силаев и др., 2008]. Выявлены три разновидности реакционных кайм: перовскитовая, вторичные шпинели в ассоциации с перовскитом в виде кайм около пикроильменита и шпинелид-титанитовая (титаномагнетитовая). Авторами этих работ было отмечено, что механизм образования этих кайм преимущественно диффузионно-метасоматический. Вторичный ильменит из реакционных кайм существенно отличается от первичного более высокой магнезиальностью и повышенным содержанием $\mathrm{Mn}, \mathrm{Ca}$ и $\mathrm{Si}$ [Силаев и др., 2008]. В работе [Клопов и др., 1984] отмечено, что титановые шпинелиды, тяготеющие к внешней границе зерна пикроильменита, образуются на наиболее позднем этапе эпигенетического изменения первичного пикроильменита.

Изменчивость состава пикроильменитов изучалась авторами работы [Геншафт и др., 2000] моделированием $P T$-условий и состава исходного материала (шихты). Было подтверждено, что содержание гейкилитового и гематитового минала в пикроильмените кимберлитов зависит от давления и температуры. При этом предполагается, что сильная изменчивость в содержании гейкелита в пикроильменитах, скорее всего, отражает сильную вещественную гетерогенность глубинного субстрата, из которого ильмениты попали в кимберлитовую магму.

Магнитные свойства первичного пикроильменита из кимберлитов Якутии достаточно полно описаны в работах [Гаранин и др., 1984; Кудрявцева, 1988]. Наиболее значимые минералы (с точки зрения магнитных свойств) - первичный пикроильменит и титаномагнетит достаточно уверенно диагностируются по термомагнитным кривым.

Данная работа посвящена изучению латеральной изменчивости пикроильменита тр. Зарница методом термомагнитного анализа (ТМА), предложенного авторами в работе [Ибрагимов, Мишенин, 2009].

\section{ОПИСАНИЕ ОБРАЗЦОВ ПИКРОИЛЬМЕНИТА И МЕТОДИКА ИССЛЕДОВАНИЙ}

Трубка Зарница относится к Далдынскому кимберлитовому полю Западной Якутии (рис. 1, a). Она очень крупная, размер рудного тела на дневной поверхности 520-540 м. На разведанную глубину (до 700 м) форма горизонтального сечения трубки остается близкой к изометричной. Трубка умеренно алмазоносная - до 0.2 карата на тонну.

Образцы пикроильменитов отобраны из керна восьми скважин, образующих субмеридиональный профиль, пересекающий тр. Зарница (см. рис. 1, б). Скважины опробовались с глубин от 0 до 130 м от их устья. Отбор проводился интервальными пробами $10-20$ м, затем пробы обогащали на специальной геолого-разведочной установке. Зерна пикроильменита отбирали с концентрата тяжелой фракции этих поинтервальных проб кимберлитов. С каждого интервала опробования в среднем было отобрано от 50 до 100 зерен пикроильменита, без техногенных сколов и трещин. Большинство зерен вытянутой формы, размером от 0.3 до 0.8 мм. Значительно реже (не более 10 зерен на 20-метровый интервал отбора) попадались зерна пикроильменита размером более 1 мм. Затем с учетом крупности зерен пикроильменита и с группированием коротких интервалов опробования были сформированы выборки, равномерно представляющие каждый 20 -метровый интервал опробования по каждой из скважин. Таким образом, всего для аналитических исследований отобрали 737 образцов пикроильменита, для которых и были проведены термомагнитные измерения.

Термомагнитные кривые зерен пикроильменита $M_{i}(T)$ (зависимость магнитного момента пробы по индуктивной намагниченности) были получены на установке дифференциального термомагнитного анализа [Буров, Ясонов, 1979] в магнитном поле напряженностью $160 \mathrm{\kappa A} / \mathrm{M}$, со скоростью нагрева 50 град/мин, в температурном интервале от $-160^{\circ} \mathrm{C}$ до $250{ }^{\circ} \mathrm{C}$.

Основой интерпретации данных ТМА является их сопоставление с результатами микрозондовых измерений. После выполнения термомагнитного анализа были отобраны 29 типовых образцов для исследования на микрозонде с целью определения их вещественного состава и его вариаций в пределах зерна. Критерием отбора являлось различие термомагнитных кривых (температура Кюри и вид кривых). 


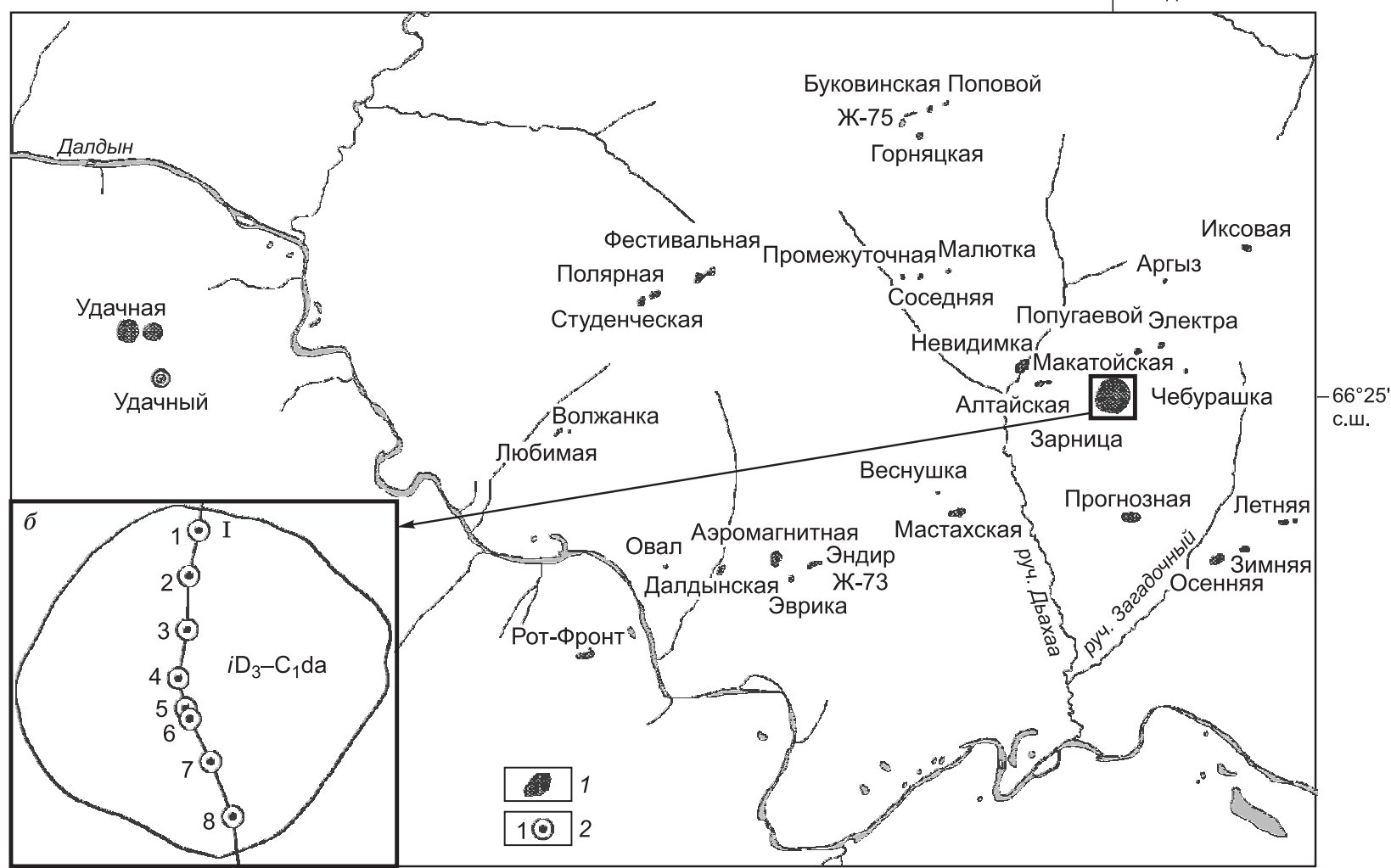

Рис. 1. $a$ - обзорная схема участка Далдынского кимберлитового поля; $\sigma$ - схема-врезка тр. Зарница.

1 - кимберлитовые тела Далдынского поля, 2 - скважины с отобранными пробами пикроильменита по профилю I через тр. Зарница.

Микрозондовые исследования проводились на сканирующем электронном микроскопе - микроанализаторе EVO GM фирмы Carl Zeiss в Междисциплинарном Центре аналитической микроскопии Приволжского (Казанского) федерального университета. На шлифованной поверхности каждого зерна по двум взаимно-перпендикулярным профилям (по 15 точек зондирования на каждом профиле) определяли элементный состав в каждой точке зондирования. Далее в каждой точке элементный состав по стандартной методике пересчитывали на содержание гематита, гейкелита и ильменита.

\section{РЕЗУЛЬТАТЫ ИССЛЕДОВАНИЙ И МЕТОДИКА ИНТЕРПРЕТАЦИИ ТЕРМОМАГНИТНЫХ КРИВЫХ}

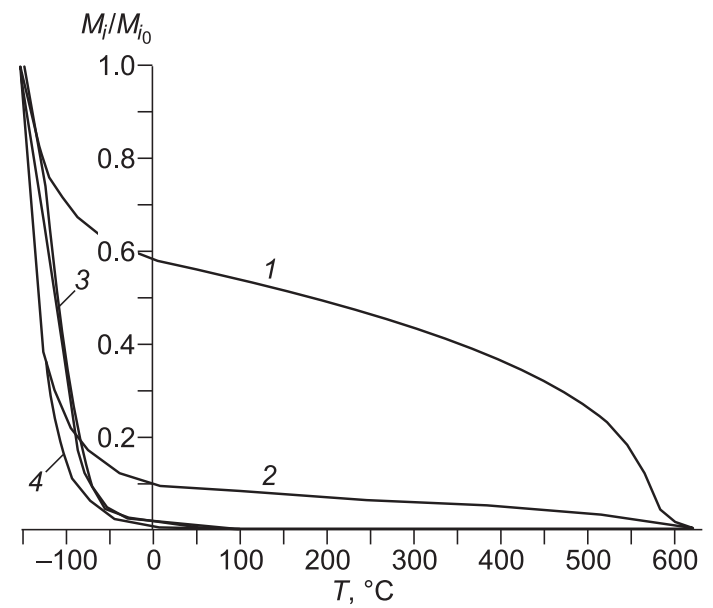

Кривые ТМА всех образцов можно подразделить на две группы. К первой группе, группе пикроильменита, относятся образцы с температурами до $100^{\circ} \mathrm{C}$, при которых магнитный момент пробы меньше 0.01 от первоначальной величины. У второй группы образцов на кривых TMА регистрируется, помимо пикроильменита, наличие титаномагнетита (магнетита) - на кривых ТМА второй группы наблюдается вторая магнитная фаза с температурой Кюри $550-600^{\circ} \mathrm{C}$ (рис. 2).

Рис. 2. Термомагнитные кривые образцов пикроильменита, отобранных по скв. 3 в интервале 50-70 м (обр. 1 и 3) и в интервале 70—90 м (обр. 2 и 4).

Пояснения см. в тексте. 
Образцы, у которых на кривых ТМА наблюдались две магнитные фазы, но первоначальный магнитный момент (при $-160{ }^{\circ} \mathrm{C}$ ) пикроильменитовой фазы примерно в 10 раз больше магнитного момента магнетитовой, были отнесены к пикроильменитовой группе. Для этих образцов применялась методика разделения пикроильменитовой и магнетитовой магнитных фаз [Ибрагимов и др., 1999].

На всех кривых TMА образцов пикроильменита, в отличие от кривых TMА магнетитсодержащих образцов, не наблюдается четкой температуры Кюри (см. рис. 2, кривые 3 и 4). Такое «размытое» ферромагнитное превращение (превращение происходит не при одной температуре, а в некотором интервале температур, образующих область Кюри) является следствием флуктуации состава по объему образца [Белов, 1959].

Таблица 1. Результаты микрозондового и термомагнитного анализа (ТМА) образцов пикроильменита

\begin{tabular}{|c|c|c|c|c|c|c|c|c|c|c|c|c|c|c|c|c|c|c|c|}
\hline \multirow{4}{*}{$\begin{array}{c}\text { № } \\
\text { образ- } \\
\text { ца }\end{array}$} & \multicolumn{13}{|c|}{ Микрозондовый анализ } & \multicolumn{6}{|c|}{ Термомагнитный анализ } \\
\hline & \multirow{2}{*}{\multicolumn{6}{|c|}{$\begin{array}{c}\text { Содержание элемента, } \\
\text { мас. \% }\end{array}$}} & \multicolumn{7}{|c|}{ Содержание минала, \% } & \multirow{3}{*}{$\begin{array}{c}\text { Доля К2 } \\
\text { в образ- } \\
\text { це }(D)\end{array}$} & \multirow{2}{*}{\multicolumn{2}{|c|}{$\begin{array}{c}\text { Компонента } 1 \\
\text { (К1) }\end{array}$}} & \multirow{2}{*}{\multicolumn{2}{|c|}{$\begin{array}{c}\text { Компонента } 2 \\
(\text { К2) }\end{array}$}} & \multirow{3}{*}{$\delta, \%$} \\
\hline & & & & & & & \multicolumn{2}{|c|}{$\mathrm{Fe}_{2} \mathrm{O}_{3}$} & \multicolumn{2}{|c|}{$\mathrm{MgTiO}_{3}$} & \multicolumn{2}{|c|}{$\mathrm{FeTiO}_{3}$} & \multirow{2}{*}{$\begin{array}{c}\text { Сум- } \\
\text { ма }\end{array}$} & & & & & & \\
\hline & $\mathrm{Mg}$ & $\mathrm{Ti}$ & $\mathrm{Fe}$ & $\mathrm{Al}$ & $\mathrm{V}$ & $\mathrm{Cr}$ & $\mathrm{Cp}$. & $\mathrm{CO}$ & Cp. & $\mathrm{CO}$ & Cp. & $\mathrm{CO}$ & & & Cp. & $\mathrm{CO}$ & Cp. & $\mathrm{CO}$ & \\
\hline $1 \_1$ & 6.4 & 39.6 & 51.6 & 0.5 & 0.7 & 1.1 & 17.4 & 1.2 & 25.4 & 2.5 & 54.5 & 3.2 & 97.3 & 0.30 & 18.1 & 1.4 & 21 & 1.5 & 3.7 \\
\hline $1 \_2$ & 6.9 & 39.7 & 50.8 & 0.5 & 0.8 & 1.2 & 17.6 & 0.9 & 27.4 & 3.2 & 52.2 & 4.0 & 97.2 & 0.20 & 17.3 & 1 & 20.4 & 1 & 1.9 \\
\hline $1 \_3$ & 6.3 & 38.7 & 52.4 & 0.5 & 0.7 & 1.3 & 18.3 & 3.7 & 25.3 & 0.8 & 53.0 & 4.3 & 97.2 & 0 & 18.4 & 1.8 & 0 & 0 & 0.5 \\
\hline $1 \_4$ & 9.0 & 44.6 & 44.7 & 0.5 & 0.8 & 0.4 & 11.3 & 0.5 & 34.6 & 0.9 & 52.2 & 1.4 & 98.0 & 0.07 & 11.3 & 1.8 & 18.3 & 1 & 3.1 \\
\hline $2 \_1$ & 9.0 & 44.6 & 44.7 & 0.5 & 0.7 & 0.4 & 11.3 & 0.6 & 34.6 & 1.0 & 52.2 & 1.2 & 98.0 & 0.05 & 12.2 & 1.4 & 18.9 & 1.5 & 8.1 \\
\hline $2 \_2$ & 7.6 & 41.5 & 48.8 & 0.5 & 0.7 & 0.8 & 15.2 & 1.8 & 29.8 & 3.2 & 52.6 & 4.7 & 97.6 & 0.33 & 14.5 & 0.3 & 16 & 2 & 4.7 \\
\hline $2 \_3$ & 6.8 & 39.9 & 50.7 & 0.5 & 0.7 & 1.4 & 17.2 & 0.5 & 26.9 & 0.9 & 53.1 & 1.2 & 97.2 & 0 & 17.4 & 0.3 & 0 & 0 & 1.4 \\
\hline $2 \_4$ & 5.9 & 37.1 & 54.1 & 0.4 & 0.6 & 1.1 & 18.1 & 0.7 & 25.4 & 1.2 & 54.1 & 1.6 & 97.5 & 0 & 18 & 0.9 & 0 & 0 & 0.8 \\
\hline $2 \_5$ & 7.1 & 40.3 & 50.0 & 0.6 & 0.7 & 1.3 & 16.5 & 0.8 & 28.0 & 1.2 & 52.5 & 1.6 & 97.1 & 0.17 & 16.4 & 0.3 & 19.5 & 1 & 1.5 \\
\hline $2 \_6$ & 7.9 & 42.2 & 47.6 & 0.7 & 0.8 & 0.9 & 14.1 & 4.0 & 30.6 & 3.1 & 52.6 & 6.0 & 97.2 & 0.10 & 14.3 & 0.3 & 18 & 1.3 & 1.2 \\
\hline $3 \_1$ & 8.1 & 43.0 & 47.0 & 0.5 & 0.7 & 0.7 & 13.3 & 0.8 & 31.6 & 1.2 & 53.1 & 2.0 & 97.8 & 0.10 & 13.1 & 0.3 & 18 & 1.5 & 1.7 \\
\hline $4 \_1$ & 6.5 & 39.1 & 52.0 & 0.5 & 0.7 & 1.2 & 18.5 & 0.6 & 25.9 & 1.1 & 52.9 & 1.7 & 97.4 & 0.20 & 19.1 & 0.3 & 20.8 & 1.5 & 3.0 \\
\hline $4 \_3$ & 8.1 & 42.1 & 47.7 & 0.5 & 0.7 & 0.9 & 14.6 & 1.0 & 31.4 & 2.2 & 51.6 & 2.2 & 97.6 & 0.13 & 14.3 & 0.3 & 18 & 1.5 & 2.1 \\
\hline 4_4 & 8.6 & 42.1 & 47.2 & 0.5 & 0.7 & 0.8 & 14.9 & 0.5 & 33.2 & 2.0 & 49.4 & 2.2 & 97.6 & 0.14 & 14.2 & 0.3 & 18 & 1.5 & 5.1 \\
\hline $5 \_1$ & 9.1 & 43.7 & 45.5 & 0.5 & 0.7 & 0.4 & 12.9 & 0.7 & 35.0 & 1.6 & 50.1 & 1.7 & 98.0 & 0.22 & 12.9 & 1.4 & 18 & 2 & 0.0 \\
\hline $5 \_2$ & 8.2 & 42.9 & 47.1 & 0.5 & 0.7 & 0.5 & 13.4 & 0.6 & 31.7 & 1.1 & 52.8 & 1.6 & 97.9 & 0.18 & 13.3 & 2.3 & 20 & 2 & 1.0 \\
\hline $5 \_3$ & 8.3 & 42.9 & 47.1 & 0.5 & 0.7 & 0.5 & 13.6 & 0.6 & 32.0 & 0.9 & 52.4 & 1.4 & 98.0 & 0.18 & 14.1 & 1 & 19 & 1.5 & 3.8 \\
\hline $5 \_4$ & 7.6 & 41.9 & 48.4 & 0.5 & 0.7 & 2.4 & 14.4 & 1.1 & 29.6 & 1.9 & 52.7 & 3.2 & 96.7 & 0.25 & 14.6 & 1.5 & 20.3 & 1.5 & 1.4 \\
\hline $5 \_5$ & 8.9 & 44.4 & 45.1 & 0.5 & 0.7 & 0.4 & 11.6 & 0.5 & 34.2 & 0.8 & 52.4 & 1.2 & 98.1 & 0.12 & 11.6 & 0.6 & 18.7 & 1.7 & 0.2 \\
\hline $5 \_6$ & 6.5 & 39.9 & 51.2 & 0.5 & 0.7 & 1.2 & 17.0 & 0.7 & 25.8 & 1.3 & 54.4 & 2.0 & 97.2 & 0.18 & 17.4 & 1.8 & 22 & 1.8 & 2.3 \\
\hline $5 \_7$ & 7.0 & 40.1 & 50.4 & 0.6 & 0.7 & 1.3 & 16.9 & 0.6 & 27.5 & 0.9 & 52.8 & 1.5 & 97.2 & 0.27 & 17.2 & 2 & 22.5 & 1.8 & 1.9 \\
\hline $5 \_8$ & 7.8 & 41.8 & 48.3 & 0.5 & 0.8 & 0.8 & 14.8 & 1.1 & 30.3 & 0.8 & 52.5 & 1.2 & 97.6 & 0.30 & 15.3 & 2 & 19 & 1.8 & 3.3 \\
\hline 5_9 & 6.4 & 39.1 & 52.1 & 0.5 & 0.7 & 1.2 & 18.5 & 0.4 & 25.6 & 0.4 & 53.3 & 0.8 & 97.4 & 0.25 & 19.2 & 2 & 23.5 & 1 & 3.7 \\
\hline 5_10 & 7.1 & 40.8 & 50.0 & 0.5 & 0.7 & 0.9 & 16.1 & 0.6 & 27.9 & 1.1 & 53.6 & 1.7 & 97.6 & 0.23 & 17 & 1.3 & 21 & 1 & 5.4 \\
\hline 5_11 & 7.3 & 40.4 & 49.7 & 0.5 & 0.7 & 1.3 & 16.7 & 0.7 & 28.8 & 2.2 & 51.7 & 1.9 & 97.2 & 0.13 & 16.7 & 0.7 & 20.4 & 1 & 0.0 \\
\hline 6_1 & 8.0 & 42.6 & 48.0 & 0.5 & 0.0 & 0.9 & 14.2 & 0.4 & 31.1 & 0.9 & 52.9 & 1.2 & 98.2 & 0.10 & 14.3 & 0.3 & 18.5 & 1 & 0.6 \\
\hline $6 \_2$ & 7.8 & 42.5 & 48.3 & 0.6 & 0.0 & 0.8 & 14.1 & 1.3 & 30.3 & 1.6 & 53.7 & 0.7 & 98.1 & 0.09 & 14.5 & 0.3 & 18.5 & 1 & 2.7 \\
\hline 7_1 & 7.9 & 42.7 & 47.8 & 0.5 & 0.0 & 3.1 & 13.6 & 0.9 & 30.3 & 2.0 & 52.9 & 3.6 & 96.8 & 0.20 & 14.8 & 1.3 & 19.5 & 2 & 8.7 \\
\hline 8_1 & 7.9 & 42.3 & 48.2 & 0.6 & 0.0 & 1.0 & 14.4 & 0.7 & 30.8 & 1.6 & 52.9 & 2.3 & 98.1 & 0.29 & 15.6 & 1.3 & 19.5 & 1 & 9.1 \\
\hline
\end{tabular}

Примечание. Микрозондовый анализ проведен по двум взаимно-перпендикулярным профилям по шлифованной поверхности зерна, в каждом профиле - 15 точек зондирования. Ср. - среднее значение; СО — стандартное отклонение; К1, К2 - основное и дополнительное распределения гематитового минала (\%) соответственно при интерпретации кривой ТМА; $D$ - доля дополнительного распределения в объеме зерна; $\delta$ - относительная погрешность (\%) определения гематитового минала основного распределения при интерпретации кривой ТМА относительно определения гематитового минала по данным микрозондирования. Микрозондовый анализ образцов пикроильменитов был выполнен в Междисциплинарном Центре аналитической микроскопии Приволжского (Казанского) федерального университета (К(П)ФУ) на сканирующем электронном микроскопе-микроанализаторе EVO GM фирмы Carl Zeiss. Аналитик Ю.Н. Осин. Термомагнитный анализ образцов пикроильменита был выполнен в палеомагнитной лаборатории Института геологии К(П)ФУ на установке ДТМА, исполнитель Ш.З. Ибрагимов. 
$a$

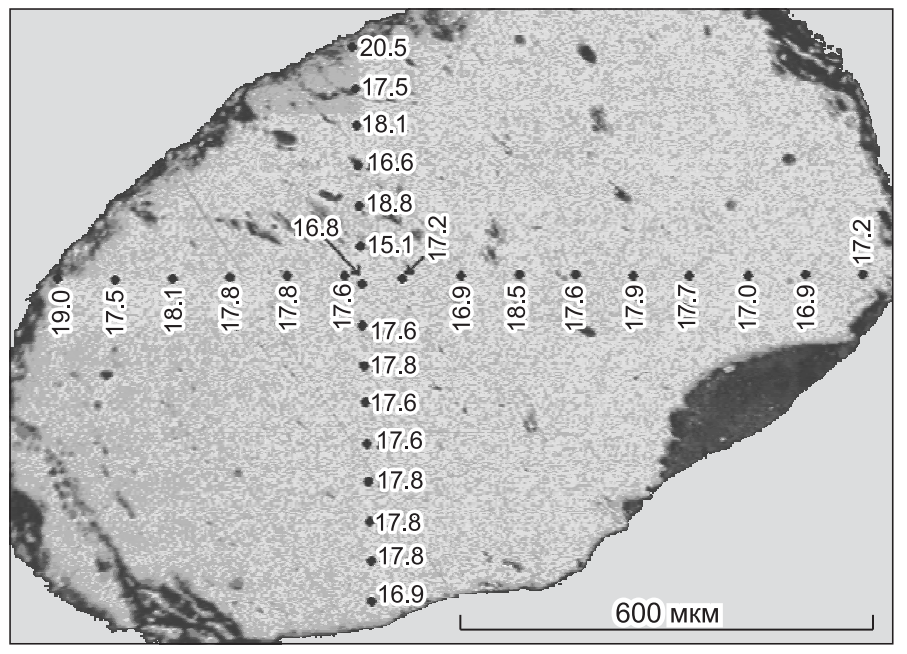

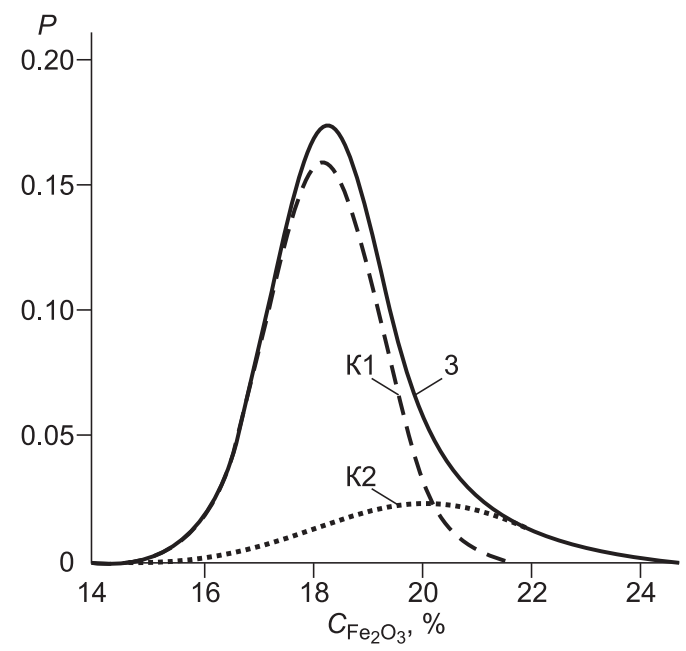

B

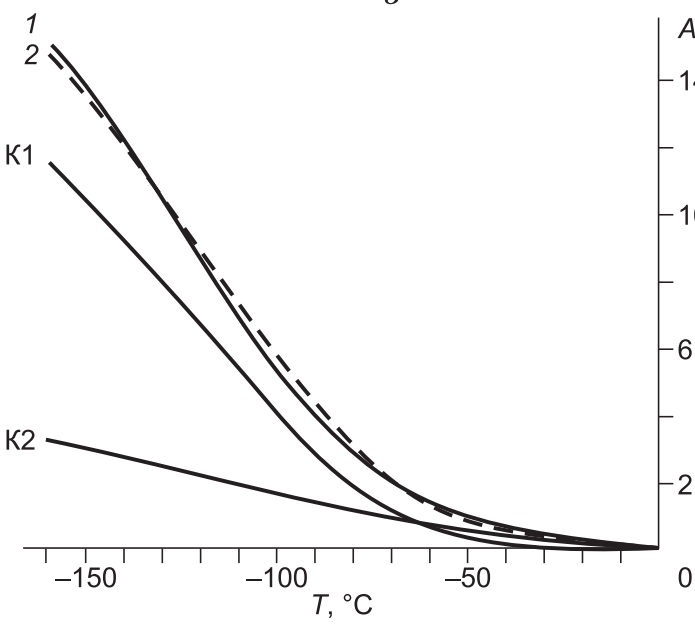

$A \cdot \mathrm{M}^{2} / \mathrm{\kappa} \Gamma$

-14 Рис. 3. $\boldsymbol{a}$ - изображение зерна пикроильменита 12 во вторичных электронах.

Показаны точки зондирования по профилям, цифры - значения гематитового минала (\%) по данным микрозондирования.

б - распределение содержания гематитового минала:

К1 - распределение первой компоненты, К2 - распределение второй компоненты, 3 - суммарное распределение. По оси ординат отложена плотность вероятности нормального распределения $(\mathrm{P})$.

B - сопоставление экспериментальной (1) и расчетной (2) кривых TMA, К1 - расчетная термомагнитная кривая первой компоненты, К2 - расчетная термомагнитная кривая второй компоненты. Ось ординат - удельный магнитный момент.

Результаты микрозондовых исследований по 29 образцам пикроильменита показаны в табл. 1. Среднее содержание гематитовой компоненты в зернах пикроильменита колеблется в интервале $11-$ 19 \%. В первом приближении колебания содержания гематитовой компоненты на плоскости микрозондового анализа описываются нормальным распределением.

В отличие от методики интерпретации термомагнитных кривых образцов пикроильменитов, предложенных в работе [Ибрагимов, Мишенин, 2009], были внесены три дополнения:

1. В работе [Ибрагимов, Мишенин, 2009] моделирование термомагнитных кривых $M(T)$ велось по нормированным кривым $M_{i}(T) / M_{i_{0}}$, где $M_{i_{0}}$ - магнитный момент образца при температуре $-160{ }^{\circ} \mathrm{C}$. При нормировании термомагнитных кривых теряется информация о магнитном моменте образца. Это может привести к значительным ошибкам определения состава ферримагнитной части зерна пикроильменита, так как удельный магнитный момент пикроильменита зависит от содержания гематитового минала [Кудрявцева, 1988]. Для того чтобы работать с удельным магнитным моментом пикроильменита, необходимо учитывать вес образца.

2. В работе [Ибрагимов, Мишенин, 2009] была показана возможность определения содержания гематитовой компоненты по данным термомагнитного анализа пикроильменитов. Для определения содержания гематитовой компоненты использовались зависимости, предложенные в работе [Кудрявцева, 1988]. В результате были получены значительные расхождения в определении состава пикроильменитов по данным микрозондового и термомагнитного анализов. Вследствие нестационарности процессов формирования диатрем, разнообразия их минерального и вещественного составов, магнитные свойства пикроильменитов могут быть индивидуальными для каждой трубки. Поэтому по 29 образцам, отобранным для микрозондового анализа, были определены частные зависимости параметров интерпретации термомагнитных кривых от содержания гематитового минала для тр. Зарница. К параметрам интерпретации относятся: температура Кюри $\left(T_{\mathrm{c}}\right)$, параметр, описывающий температурный ход кривой TMА $(b)$ и на- 
чальный магнитный момент $\left(M_{i_{0}}\right)$. Были получены следующие зависимости: $T_{\mathrm{c}}=0.464 \cdot C^{2}-4.43 \cdot C-123$ $\left(C\right.$ - содержание гематитового минала в \%), с величиной достоверности аппроксимации $R^{2}=0.9$; зависимость начального удельного магнитного момента $M_{i_{\mathrm{o}}} / P(P-$ вес образца) от содержания гематитового минала, $M_{i_{\mathrm{o}}} / P=0.0008 \cdot C-0.003$, с величиной достоверности аппроксимации $R^{2}=0.9 ; b=6.24 \cdot C+66$. $R^{2}=0.82$

3. На всех кривых ТМА образцов пикроильменита регистрируется «размытая» температура Кюри, обусловленная переменным составом пикроильменита. Поэтому для интерпретации кривых ТМА необходимо вводить, помимо основной компоненты состава пикроильменита, дополнительную компоненту (см. табл. 1). К1 и К2 - основная и дополнительная компонента соответственно. На основную низкотемпературную компоненту приходится бо́льшая часть магнитного момента образца. Это предположение о неоднородности состава зерен пикроильменитов было подтверждено микрозондовым анализом 29 образцов. На рис. 3 показана фотография зерна пикроильменита в отраженных электронах и интерпретация термомагнитной кривой этого же образца. По данным микрозондового анализа, участки зерна с повышенным содержанием гематитового минала тяготеют к внешним частям зерна.

\section{ОБСУЖДЕНИЕ РЕЗУЛЬТАТОВ}

Данные обработки кривых термомагнитного анализа образцов, где по кривым ТМА диагностировался только пикроильменит (598 зерен), приводятся в табл. 2. В этой таблице три раздела: основное распределение, дополнительное распределение и доля дополнительного распределения в весе зерна. Основное распределение описывает содержание гематитовой компоненты большей части зерна пикроильменита. Дополнительное распределение требуется для описания более высокотемпературного «хвоста» на кривой термомагнитного анализа, за которую отвечает часть зерна пикроильменита с более высоким содержанием гематитового минала. Доля дополнительного распределения - часть зерна пикроильменита с более высоким содержанием гематитового минала по отношению ко всему зерну.

Рентгеновские дифрактограммы показывают, что в неоднородном по составу зерне пикроильменита наблюдаются рефлексы только ильменита, других рефлексов нет. Микрозондовые наблюдения свидетельствуют о том, что зерна пикроильменита с незначительными вариациями состава в центральной части зерна однородны, и только на краях зерен состав резко отличен от центральной части. Изменения всегда одни и те же - центральная часть зерна более магнезиальна, а краевая часть (если она есть) обогащена железом. При диффузионно-метасоматическом процессе образования реакционных кайм вторичный ильменит существенно отличается от первичного более высокой магнезиальностью и повышенным содержанием $\mathrm{Mn}, \mathrm{Ca}$ и $\mathrm{Si}$ [Силаев и др., 2008]. В нашем случае при микрозондовых исследованиях значимого содержания $\mathrm{Mn}, \mathrm{Ca}$ и $\mathrm{Si}$ в краевых частях зерен не обнаружено.

Можно предположить, что неоднородность состава зерен пикроильменита обусловлена сменой условий кристаллизации - центральная «магнезиальная» часть зерна образовалась в более глубинных условиях, а более «железистая» оторочка в менее глубинных. Если это предположение верно, то параметр «доля вторичного распределения» будет отражать динамику процесса образования оторочки. Необходимо отметить, что примерно у $5 \%$ зерен пикроильменита при обработке термомагнитных кривых дополнительного распределения гематитового минала не понадобилось - кривые ТМА описывались одним распределением, но среднее значение содержания единственной компоненты у этих образцов пикроильменита было выше $16 \%$.

Изменение содержания гематитового минала основного распределения $(C)$ и доли дополнительного распределения $(D)$ по скважинам бурового профиля показаны на рис. 4. Центральная часть трубки (скв. $3,4,5$ и 6) характеризуется повышенными значениями содержания гематитового минала в пикроильмените - в среднем выше 14 \%. Доля дополнительного распределения в этих скважинах значительно изменяется по вертикали. Исключением является скв. 6 , особенно параметр $D-$ значения низкие и практически постоянные. Для скважин, расположенных на краях трубки (скв. 1 и 8), характерны низкие и малоизменчивые значения параметров $C$ и $D$. Можно отметить также, что северная окраина трубки (скв. 1 и 2) отличается от южной (скв. 7 и 8 ) пониженными значениями $C$ и большей изменчивостью по вертикали параметра $D$.

Таким образом, распределение пикроильменита имеет статистический характер, и для получения более достоверных данных необходимо увеличивать представительность анализа. Одним из способов является укрупнение выборки до скважины. В табл. 2 эти данные показаны как интервал отбора зерен пикроильменита по всей скважине.

Представляет интерес распределение образцов пикроильменита с магнетитом по скважинам, показанное на рис. 5. В коллекции из 737 зерен пикроильменита магнетит на кривых TMА диагностировался в 139 образцах. Так как количество интервалов опробования в скважинах разное, то для объективности рассчитывалось удельное количество пикроильменита с магнетитом $(N)$ - общее количество 
Таблица 2. Результаты определения содержания гематитового минала для К1 и К2 (\%) и параметра $D$ по данным термомагнитного анализа образцов пикроильменита, отобранных из керна восьми скважин

\begin{tabular}{|c|c|c|c|c|c|c|c|c|c|c|c|}
\hline \multirow{2}{*}{$\begin{array}{l}\text { № } \\
\text { скв. }\end{array}$} & \multirow{2}{*}{$H, \mathrm{~m}$} & \multirow{2}{*}{$\begin{array}{c}\text { Коли- } \\
\text { чество } \\
\text { проб }\end{array}$} & \multicolumn{3}{|c|}{ Основное распределение (К1) } & \multicolumn{3}{|c|}{$\begin{array}{c}\text { Дополнительное распределе- } \\
\text { ние (К2) }\end{array}$} & \multicolumn{3}{|c|}{$\begin{array}{c}\text { Доля дополнительного рас- } \\
\text { пределения }(D)\end{array}$} \\
\hline & & & Cp. & $\mathrm{CO}$ & мин.- -макс. & Cp. & $\mathrm{CO}$ & мин.-макс. & Cp. & $\mathrm{CO}$ & мин.- макс. \\
\hline \multirow{5}{*}{1} & 20 & 19 & 13.3 & 2.64 & $8.8-16.9$ & 18.1 & 0.98 & $16.5-19.5$ & 0.12 & 0.08 & $0.03-0.25$ \\
\hline & 40 & 19 & 13.6 & 2.80 & $9.1-17.9$ & 18.1 & 0.87 & $17.5-20.0$ & 0.10 & 0.04 & $0.04-0.17$ \\
\hline & 60 & 21 & 13.9 & 2.61 & $10-17.8$ & 18.3 & 1.02 & $16.5-20.0$ & 0.14 & 0.07 & $0.04-0.27$ \\
\hline & 80 & 20 & 13.2 & 2.31 & $9.8-16.7$ & 17.7 & 1.07 & $16.5-20.0$ & 0.14 & 0.07 & $0.04-0.28$ \\
\hline & $10-90$ & 79 & 13.5 & 2.54 & $8.8-17.8$ & 18.0 & 0.99 & $16.5-20.0$ & 0.13 & 0.07 & $0.03-20.0$ \\
\hline \multirow{6}{*}{2} & 40 & 13 & 11.4 & 1.35 & $9.9-13.7$ & 18.4 & 0.70 & $17.4-19.8$ & 0.20 & 0.20 & $0.05-0.52$ \\
\hline & 60 & 12 & 12.0 & 1.28 & $10.1-13.8$ & 18.8 & 0.98 & $17.5-20.7$ & 0.26 & 0.15 & $0.08-0.49$ \\
\hline & 80 & 14 & 11.7 & 1.19 & $9.4-13.2$ & 18.6 & 0.97 & $16.9-20.2$ & 0.17 & 0.11 & $0.06-0.42$ \\
\hline & 100 & 14 & 13.0 & 3.24 & $9.2-18.6$ & 18.4 & 0.91 & $17.5-20.0$ & 0.11 & 0.05 & $0.05-0.20$ \\
\hline & 120 & 13 & 10.5 & 0.68 & $9.4-11.3$ & 18.7 & 0.77 & $17.2-19.5$ & 0.13 & 0.08 & $0.05-0.25$ \\
\hline & $30-130$ & 66 & 11.8 & 2.01 & $9.2-18.6$ & 18.6 & 0.85 & $16.9-20.7$ & 0.17 & 0.13 & $0.05-0.52$ \\
\hline \multirow{4}{*}{3} & 40 & 29 & 15.3 & 2.11 & $10.7-19.1$ & 19.3 & 1.22 & $16.7-20.9$ & 0.16 & 0.06 & $0.06-0.25$ \\
\hline & 60 & 37 & 15.6 & 1.87 & $12.4-18.8$ & 19.5 & 1.48 & $17.0-21.8$ & 0.20 & 0.08 & $0.10-0.40$ \\
\hline & 80 & 33 & 16.2 & 1.91 & $12.5-19.4$ & 19.9 & 1.46 & $17.0-22.7$ & 0.22 & 0.06 & $0.12-0.42$ \\
\hline & $30-90$ & 99 & 15.7 & 1.97 & $10.7-19.4$ & 19.5 & 1.39 & $16.7-22.7$ & 0.19 & 0.07 & $0.06-0.42$ \\
\hline \multirow{4}{*}{4} & 40 & 15 & 15.4 & 1.05 & $13.1-16.9$ & 20.0 & 0.74 & $18.4-21.1$ & 0.25 & 0.06 & $0.11-0.32$ \\
\hline & 60 & 19 & 14.2 & 1.82 & $11.1-16.7$ & 19.0 & 1.00 & $17.2-20.5$ & 0.14 & 0.08 & $0.04-0.27$ \\
\hline & 80 & 19 & 15.0 & 2.52 & $10.9-18.5$ & 18.8 & 0.41 & $18.5-19.5$ & 0.11 & 0.06 & $0.04-0.22$ \\
\hline & $30-90$ & 53 & 14.9 & 1.98 & $10.9-18.5$ & 19.3 & 0.94 & $17.2-21.1$ & 0.17 & 0.09 & $0.04-0.32$ \\
\hline \multirow{3}{*}{5} & 60 & 24 & 16.3 & 1.99 & $12.5-20.0$ & 19.3 & 1.59 & $17.0-22.0$ & 0.17 & 0.06 & $0.09-0.30$ \\
\hline & 80 & 26 & 15.6 & 1.92 & $13.2-18.7$ & 19.5 & 1.81 & $17.0-21.8$ & 0.20 & 0.05 & $0.14-0.30$ \\
\hline & $50-90$ & 50 & 16.1 & 1.97 & $12.5-20.0$ & 19.4 & 1.65 & $17.0-22.0$ & 0.18 & 0.06 & $0.09-0.30$ \\
\hline \multirow{5}{*}{6} & 40 & 19 & 14.2 & 1.99 & $11.1-18.5$ & 18.6 & 0.56 & $17.5-19.6$ & 0.11 & 0.05 & $0.03-0.19$ \\
\hline & 60 & 16 & 14.3 & 2.40 & $11.3-19.1$ & 17.8 & 1.16 & $15.0-19.0$ & 0.10 & 0.06 & $0.02-0.22$ \\
\hline & 80 & 17 & 14.2 & 3.05 & $10.4-18.9$ & 18.1 & 0.52 & $17.0-19.0$ & 0.07 & 0.04 & $0.03-0.18$ \\
\hline & 120 & 16 & 13.1 & 1.81 & $11.0-17.1$ & 18.0 & 1.44 & $16.4-21.8$ & 0.10 & 0.06 & $0.03-0.23$ \\
\hline & $30-130$ & 68 & 14.0 & 2.37 & $10.4-19.1$ & 18.1 & 1.03 & $15.0-21.8$ & 0.10 & 0.05 & $0.02-0.23$ \\
\hline \multirow{5}{*}{7} & 40 & 17 & 14.5 & 2.06 & $11.3-18.0$ & 17.5 & 0.44 & $17.1-18.4$ & 0.08 & 0.03 & $0.04-0.13$ \\
\hline & 60 & 15 & 14.7 & 2.19 & $11.0-17.6$ & 18.1 & 0.69 & $17.0-19.0$ & 0.09 & 0.03 & $0.05-0.13$ \\
\hline & 100 & 17 & 15.9 & 1.87 & $13.1-18.4$ & 18.8 & 0.86 & $17.5-20.0$ & 0.12 & 0.03 & $0.09-0.16$ \\
\hline & 120 & 19 & 14.0 & 2.38 & $11.0-18.7$ & 17.9 & 0.85 & $16.4-19.5$ & 0.09 & 0.04 & $0.04-0.15$ \\
\hline & $30-130$ & 68 & 14.7 & 2.19 & $11.0-18.7$ & 18.0 & 0.82 & $16.4-20.0$ & 0.09 & 0.03 & $0.04-0.16$ \\
\hline \multirow{6}{*}{8} & 20 & 21 & 13.8 & 2.14 & $9.6-17.2$ & 17.9 & 0.81 & $16.5-19.0$ & 0.08 & 0.03 & $0.04-0.16$ \\
\hline & 40 & 21 & 15.0 & 2.80 & $10.0-18.4$ & 18.7 & 1.00 & $17.5-20.0$ & 0.06 & 0.03 & $0.02-0.10$ \\
\hline & 60 & 26 & 14.0 & 1.99 & $10.6-18.0$ & 17.7 & 0.95 & $16.0-19.0$ & 0.09 & 0.04 & $0.02-0.16$ \\
\hline & 80 & 24 & 13.9 & 2.03 & $10.1-17.6$ & 18.5 & 1.08 & $17.3-21.4$ & 0.09 & 0.05 & $0.01-0.18$ \\
\hline & 100 & 23 & 12.6 & 1.70 & $10.0-15.5$ & 18.0 & 1.00 & $16.3-19.5$ & 0.08 & 0.06 & $0.02-0.20$ \\
\hline & $10-100$ & 115 & 13.8 & 2.22 & $9.6-18.4$ & 18.1 & 1.08 & $16.0-21.4$ & 0.08 & 0.04 & $0.01-0.20$ \\
\hline
\end{tabular}

Примечание. $H$ - значения глубин отбора от поверхности трубки. мин.-макс. — размах выборки. Термомагнитный анализ образцов пикроильменита был выполнен в Палеомагнитной лаборатории Института геологии К(П)ФУ на установке ДТМА, исполнитель Ш.З. Ибрагимов. 


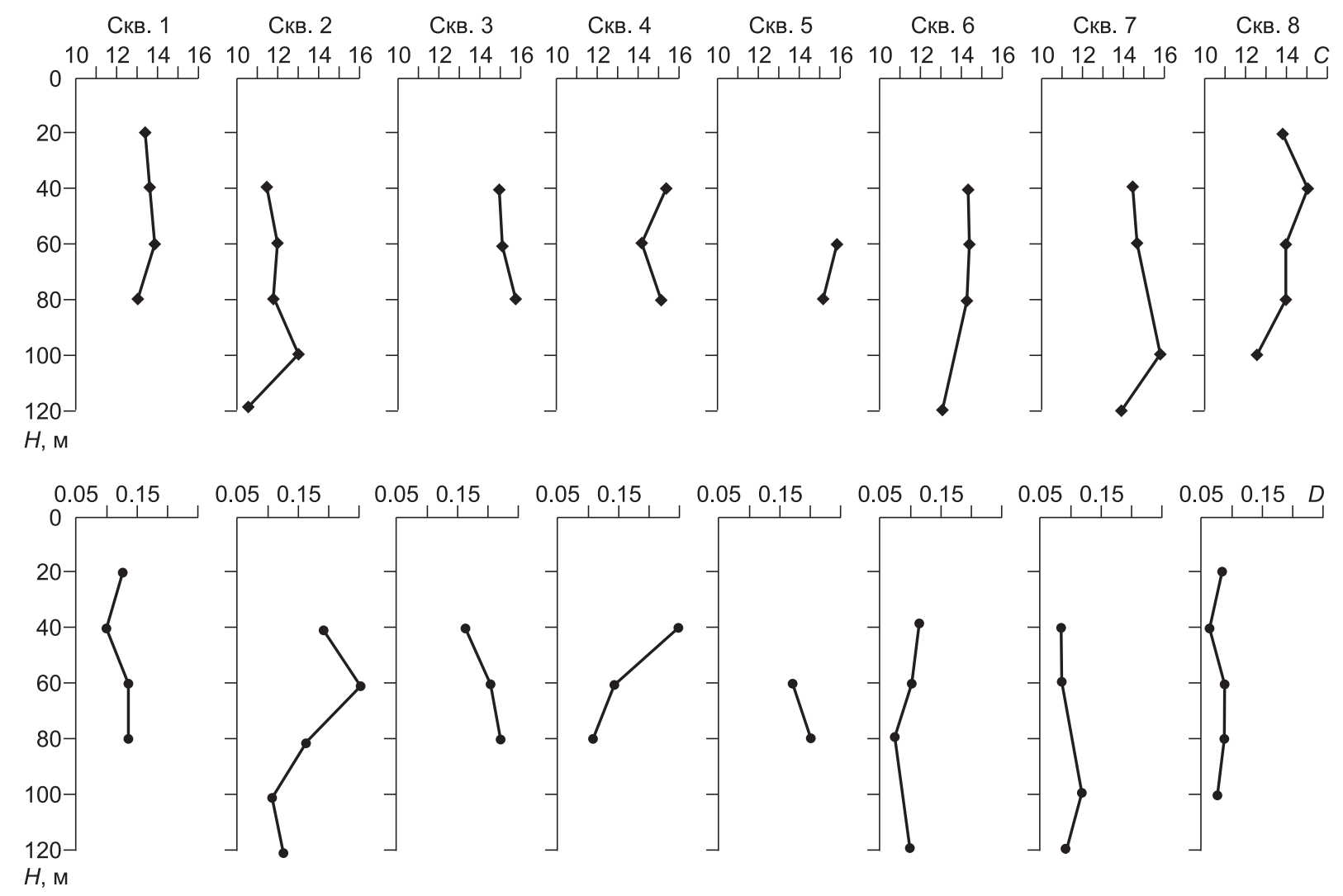

Рис. 4. Распределения среднего содержания гематитового минала $(C, \%)$ и доли дополнительного распределения $(D)$ по скважинам бурового профиля через тр. Зарница.

данных зерен нормировалось на число интервалов опробования. В скв. 4, пробуренной практически в центре трубки, наблюдается максимальное количество зерен пикроильменита с магнетитом, а минимальное количество - у скважин, пробуренных по краям трубки. В работе [Гаранин, 2006] приведены результаты исследований магнетита из кимберлитов тр. Зарница. В этой работе отмечается, что магнетит из кимберлитов, отобранных по бортам трубки, образовался в «жестких», закалочных условиях на стадии ее становления. А магнетит внутри объема трубки образовался в более «мягких» (с малыми градиентами температур) условиях. Несмотря на то, что генезис магнетита из кимберлитов отличается от магнетита зерен пикроильменита, результаты подобны. Таким образом, присутствие пикроильменита с магнетитом указывает на особенности режима формирования кимберлитового тела.

Значение доли дополнительного распределения $D$ по скважинам заметно разнятся (см. рис. 5). В какой-то мере распределение данного параметра подобно распределению магнетита в зернах пикроильменита - в краевых частях трубки значения ниже, чем в центральной части. В целом закономерности распределения параметров $C$ и $D$ по латерали аналогичны закономерностям распределения этих параметров по вертикали.

Если дополнительное распределение гематитовой компоненты в зернах пикроильменита отражает посткристаллизационные процессы, то логично предположить, что основное распределение отражает первичные, глубинные условия кристаллизации пикроильменита. Закономерности изменения основного распределения K1 и доли дополнительного распределения $D$ можно интерпретировать таким образом: пикроильменит центральной части трубки образовался при более низких $P T$-параметрах, и динамика движения кимберлитовой массы до поверхности была низкая. Учитывая большее количество пикроильменита с магнетитом, режим был более смещен в сторону восстановительных условий по сравнению с краевыми частями трубки. В краевых частях трубки при контакте с вмещающими породами расплавленный субстрат застывал в режиме «закалки», и каймы, обогащенные гематитовой компонентой, не успели образоваться.

На рис. 5 показана алмазоносность тр. Зарница по буровому профилю. Сравнение графиков распределений параметров $N, C$ и $D$ с алмазоносностью показывает их подобие. Возможно, это указывает на их общность, обусловленную условиями формирования кимберлитового тела. 


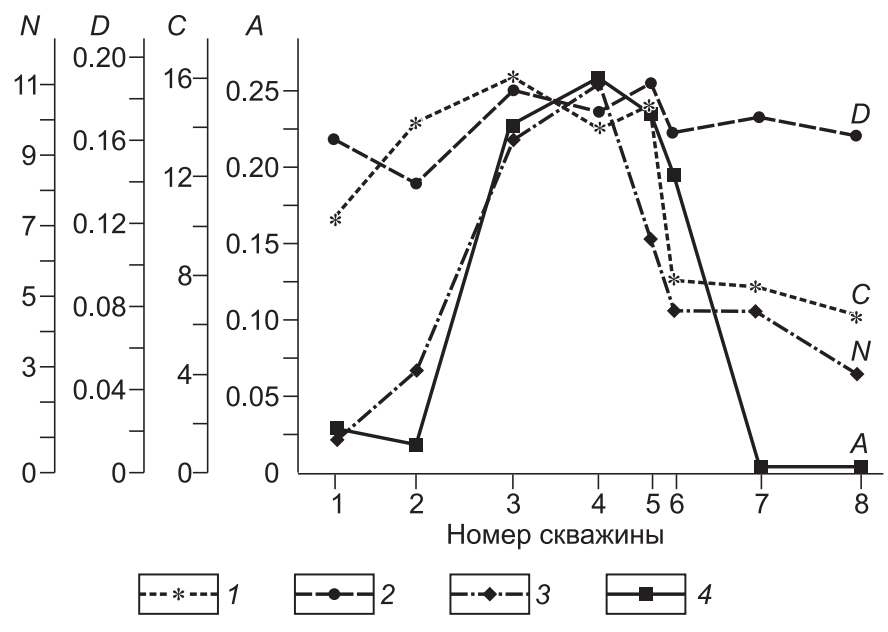

Рис. 5. Распределения параметров интерпретации кривых ТМА и алмазоносности тр. Зарница по буровому профилю.

1 - содержание гематитового минала пикроильменита $C$ приведено в процентах; 2 - доля дополнительного распределения $D$ - в относительных единицах; 3 - количество пикроильменита $N$ - в кристаллах; 4 - алмазоносность тр. Зарница $A-$ в каратах на тонну.

условиях, что, с одной стороны, создавало бдагоприятные условия дея сохран гой, - приводило к увеличению гематитового минала в пикроильмените и увеличению количества пикроильменита с магнетитом. Учитывая достаточно резкие колебания магнитных параметров и алмазоносности, можно предположить наличие не менее двух самостоятельных подводящих каналов поступления кимберлитовой магмы с различными $P T$-параметрами и частичное перемешивание кимберлитового вещества в верхней (диатремовой) части трубки. В целом очевидно, что именно многоактное становление кимберлитового тела в меняющихся термодинамических условиях обусловило сложный характер распределения пикроильменита и изменение его магнитных свойств.

\section{ВЫвОДЫ}

Термомагнитные кривые подавляющего большинства зерен пикроильменита тр. Зарница аппроксимируются двумя распределениями содержания гематитового минала. Большую часть зерна пикроильменита можно описывать основным распределением, меньшую часть - дополнительным распределением. Среднее значение гематитового минала дополнительного распределения всегда больше, чем у основного. Микрозондовые исследования показали, что центральная часть зерна описывается основным распределением, а периферийная оторочка зерна соответствует дополнительному распределению. Рентгеновские дифрактограммы образцов пикроильменита с различными значениями основного и дополнительного распределения показали наличие рефлексов только ильменита.

На основании анализа распределения доли основного и дополнительного распределений по объему зерен пикроильменита различных скважин сделаны выводы о сравнительной динамике образования зерен пикроильменита, отобранных в различных участках поверхности тр. Зарница.

Установлено общее подобие распределений удельного количества пикроильменита с магнетитом, доли дополнительного распределения в пикроильмените и алмазоносности в кимберлитовой тр. Зарница, указывающие на сложный многоактный (пульсационный) характер ее формирования в меняющихся термодинамических и окислительно-восстановительных условиях.

\section{ЛИТЕРАТУРА}

Алымова Н.В., Костровицкий С.И. Пикроильменит из кимберлитовых трубок куста Зарница (Далдынское поле) // Сборник избранных трудов научно-технических конференций. Иркутск, ИрГТУ, 2002, с. $135-139$.

Амшинский А.Н., Похиленко Н.П. Особенности состава пикроильменита из кимберлитовой трубки Зарница // Геология и геофизика, 1983 (11), с. 116-119.

Белов К.П. Магнитные превращения. М., Физматгиз, 1959, 259 с.

Бовкун А.В., Гаранин В.К., Кудрявцева Г.П., Серов И.В. Генетические аспекты особенностей состава микрокристаллических шпинелидов из связующей массы кимберлитов Якутии // Геология алмазов - настоящее и будущее (геологи к 50-летнему юбилею г. Мирный и алмазодобывающей промышленности России), Воронеж, ВГУ, 2005, с. 1499-1520.

Буров Б.В., Ясонов П.Г. Введение в дифференциальный термомагнитный анализ горных пород. Казань, КГУ, 1979, 168 с.

Гаранин В.К. Минералогия кимберлитов и родственных им пород алмазоносных провинций России в связи с их генезисом и поисками: Автореф. дис. ... д.г.-м.н. М., 2006, 42 с. 
Гаранин В.К., Кудрявцева Г.П., Сошкина Л.Т. Ильменит из кимберлитов. М., Изд-во Моск. унта, 1984, 240 c.

Гаранин В.К., Жиляева В.А., Кудрявцева Г.П., Саврасов Д.И., Сафрошкин В.Ю., Трухин В.И. Минералогические факторы магнетизма кимберлитовых пород Якутии // Изв. вузов. Серия геологическая, 1986, № 11, с. 82-100.

Геншафт Ю.С., Илупин И.П. Каймы изменения ильменитов в кимберлитах // Минералогический журнал, 1982, т. 4, № 4, с. $79-84$.

Геншафт Ю.С., Цельмович В.А., Гапеев А.К. Пикроильменит: факторы, определяющие его состав // ДАН, 2000, т. 373, № 3, с. 377-381.

Ибрагимов Ш.3., Мишенин С.Г. Информативность термомагнитного анализа при исследованиях пикроильменитов // Геология и геофизика, 2009, т. 50 (11), с. 1246-1253.

Ибрагимов Ш.З., Ясонов П.Г., Денисов И.Г. Разложение на компоненты кривых температурной зависимости намагниченности насыщения многофазной ферримагнитной фракции образцов горных пород // Изв. РАН. Сер. физика Земли. 1999, № 12, с. 65-69.

Клопов В.И., Малов Ю.В., Овсянников Е.А. Реакционные каймы на пикроильменитах из кимберлитов // Геохимия, 1984, № 10, с. 1466-1473.

Кудрявцева Г.П. Ферримагнетизм природных оксидов. М., Недра, 1988, 232 с.

Силаев В.И., Тарских О.В., Сухарев А.Е., Филиппов В.Н. Келифитизация мантийного пикроильменита на примере алмазоносной трубки Зарница // Вестн. ИГ Коми НЦ УрО РАН, 2008, № 5, с. 5-10. 